\title{
Víctor Lara Bermejo* Pragmatics and the emergence of a subject in Peninsular Spanish
}

\author{
https://doi.org/10.1515/iber-2018-0020
}

Resumen: El andaluz es conocido por haber nivelado en un solo pronombre el tratamiento en plural. Dicha forma (ustedes) es sintácticamente 3pl, pero induce tanto concordancia 3pl como concordancia 2pl. Los datos disponibles del siglo pasado indican que los hablantes andaluces no distinguían la formalidad y la informalidad y que habían perdido la diferencia pragmática que sí se da en el resto del español peninsular. Sin embargo, un nuevo trabajo de campo arroja más luz a este fenómeno y revela que ustedes no ha sido sujeto, sino un vocativo que funcionaba como tópico. Asimismo, durante los cien años que han pasado entre la última información disponible y el nuevo trabajo de campo, ustedes ha pasado por un proceso mediante el cual ha eliminado cualquier otra forma de tratamiento y se ha convertido en un sujeto por completo. Este artículo pretende proporcionar una explicación lingüística y geográfica que justifique el cambio pragmático atestiguado en Andalucía, las fases que este fenómeno ha producido y su evolución en el último siglo.

Palabras claves: Concordancia, andaluz, nivelación pragmática, sujeto, topicalización

Abstract: Andalusian Spanish is said to have levelled in one pronoun the address in plural. This term, ustedes, syntactically 3pl, can induce $2 \mathrm{pl}$ and $3 \mathrm{pl}$ agreements. The data available from last century show that Andalusian speakers no longer distinguished between formality and informality and had lost the pragmatic difference attested elsewhere in Peninsular Spanish. However, new fieldwork sheds light on this phenomenon and reveals that ustedes was not a subject, but a vocative that worked as a topic. Likewise, during the century that passed between the latest data available and the new fieldwork, ustedes has undergone a process by which it has supplanted any other term of address and has become a full subject. This article aims to provide a linguistic and geographical explanation that justifies the pragmatic change attested in Andalusia, the stages this phenomenon has produced, and its evolution in the last hundred years.

*Corresponding author: Víctor Lara Bermejo, Università Ca’ Foscari Venezia, Italy, E-Mail: viktoresc@hotmail.com 
Keywords: Agreement, Andalusian Spanish, pragmatic levelling, subject, topicalisation

\section{Introduction}

The second person pronoun system in Peninsular Spanish distinguishes the number of addressees as well as the communicative situation. It relies on its own pronoun to address someone in a formal situation and another one for an informal situation, and the same applies for the plural (Table 1).

Table 1: Forms of address system in current Peninsular Spanish

\begin{tabular}{lll}
\hline & Informality & Formality \\
\hline Singular & Tú & Usted \\
\hline Plural & Vosotros & Ustedes \\
\hline
\end{tabular}

The system represented in Table 1 is attested throughout Peninsular Spanish, excepting the western part of Andalusia, where the plural paradigm changed in the $18^{\text {th }}$ century (Fernández 2012). The singular, however, has remained unchanged. As Table 1 shows, in plural vosotros plus 2pl inflections denote informality, while ustedes plus third person plural (3pl) inflections denote formality. Nevertheless, the south-western area of Andalusia, in southern Spain, has eliminated this distinction by favouring the levelling in ustedes (Map 1).

This particularity, apart from not being prestigious and being mainly used by elderly speakers with a low educational background and from rural areas, induces two agreements: 2pl and 3pl, as shown in (1), (2), (3) and (4) and Table 2.

(1) Ustedes vais con vuestros padres a la playa You go-2PL.PREs.Ind. with Poss.2PL. parents to the beach ('You are going with your parents to the beach')

(2) Ustedes se quedáis en casa el domingo You REFL.3PL stay-2PL.PRES.IND. at home on Sunday ('You are staying at home this Sunday')

(3) A ustedes os gusta el café To you DAT.2PL like-3sg.PREs.InD. the coffee ('You like coffee') 
(4) Ustedes estuvieron trabajando hasta tarde You be-3PL.PERF.Ind. working until late ('You were working until late')

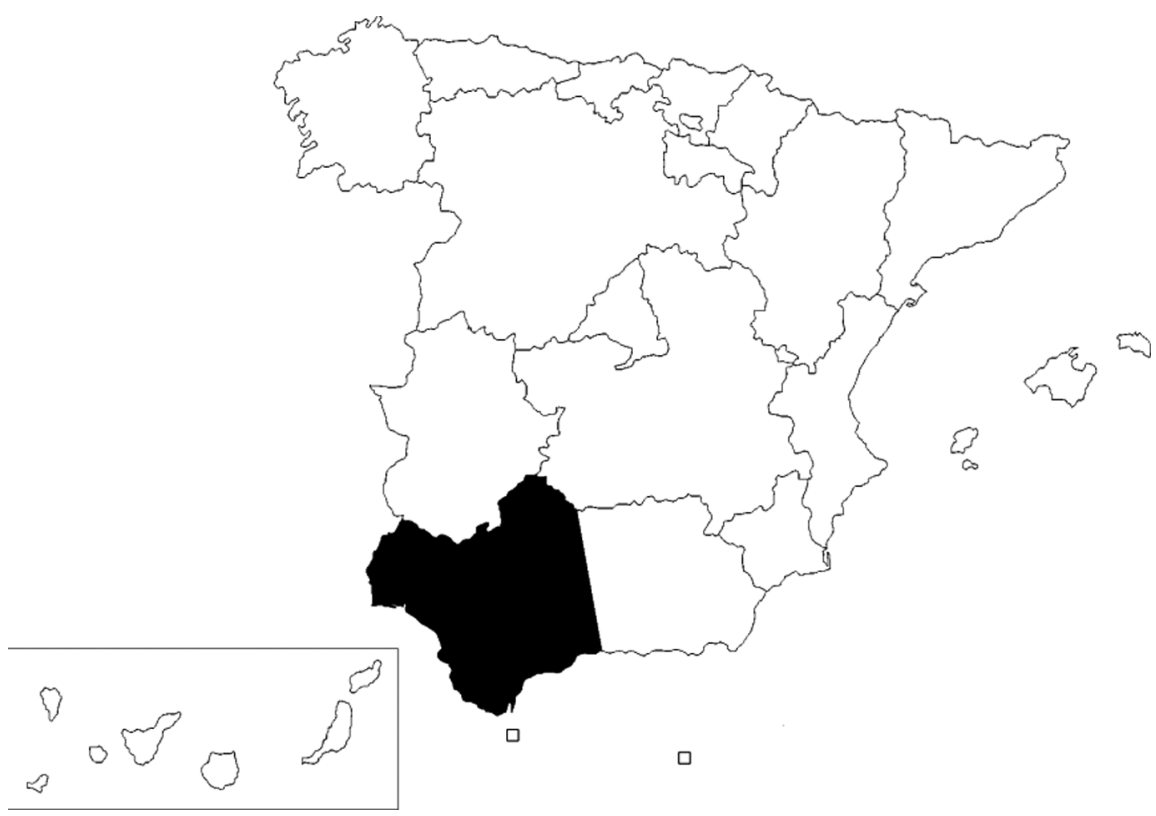

Map 1: Extension of the ustedes phenomenon in the literature

Table 2: Plural forms of address system in current Peninsular Spanish

\begin{tabular}{lll}
\hline & Standard Spanish & West Andalusia \\
\hline Formality & Ustedes $+3 \mathrm{pl}$ & Ustedes $+3 \mathrm{pl} / 2 \mathrm{pl}$ \\
\hline Informality & Vosotros $+2 \mathrm{pl}$ & Ustedes $+3 \mathrm{pl} / 2 \mathrm{pl}$ \\
\hline
\end{tabular}

These examples are a sample of the disagreements attested between ustedes and the rest of the elements anchoring this pronoun. Although each of them is inclined to be construed both in 2pl and 3pl, the fact is that Alvar (1996), Cano (2004), Lapesa (2000), Menéndez Pidal (2005), Mondéjar (1970) or Penny (2004) have always pointed out that the reflexive and the verb tensed in past simple adopt the 3pl, whereas the other elements (even any other verb tense) agree in 2pl (Table 3). 
Table 3: Agreement mismatches in West Andalusia

\begin{tabular}{|c|c|c|c|c|c|c|}
\hline & $\begin{array}{l}\text { Stressed } \\
\text { pronoun }\end{array}$ & Reflexive & Past simple & $\begin{array}{l}\text { Other verb } \\
\text { tenses }\end{array}$ & Objects & Possessive \\
\hline Agreement & Ustedes (3pl) & $3 \mathrm{pl}$ & $3 p l$ & $2 \mathrm{pl}$ & $2 \mathrm{pl}$ & $2 \mathrm{pl}$ \\
\hline
\end{tabular}

Real Academia Española (RAE) (2009) even suggests that the concatenation of both pronouns has been recorded in this area (5).

(5) Ustedes vosotros sois hermanos

You-3Pl. you-2PL. be-2PL.PRES.IND. siblings

('You you are siblings')

In order to demonstrate the accuracy of these statements, as well as the linguistic behaviour of these disagreements, I have obtained data of $2 \mathrm{pl}$ pronouns from linguistic atlases and from specific fieldwork carried out to elicit as many 2pl inflections as possible. Below, I will present the results and I will discuss the theoretical reasons why these disagreements occur.

\section{Results}

\subsection{ALPI}

The first work from which it is possible to extract some data about this phenomenon is the Linguistic Atlas of the Iberian Peninsula (ALPI). This atlas was conceived by Menéndez Pidal and the data were collected by Navarro Tomás and a team of researchers during the middle of the $20^{\text {th }}$ century. This fieldwork was intended to record all the syntactic, morphological, phonetic and lexical particularities of all the Romance languages spoken in the Iberian Peninsula. For this reason, they designed a questionnaire with pre-established sentences and words that elderly male informants with a low educational background had to repeat, based on their vernacular variety (Sanchís Guarner 1972). In the case of the 2pl pronouns system, there are eleven sentences that prompt the emergence of the stressed pronoun, the reflexive, the verb (present indicative, present subjunctive and imperative), as well as the accusative pronoun. Additionally, two of the eleven sentences were set for a polite context, in order to find not only the possible formal pronouns, but the possible person disagreements, depending on the degree of politeness. The data can be analysed on the basis of three parameters: geographical, grammatical and pragmatic.

From a geographical point of view, this phenomenon was attested in western Andalusia, specifically in the districts of Huelva, Cadiz, Seville, most of Cordoba 
and most of Malaga. Furthermore, the ustedes particularity evidenced four different stages, based upon the extension of the $3 \mathrm{pl}$ agreement, that is, the syntactic agreement. Thus, the first phase was characterised by the emergence of ustedes as the single pronoun in $2 \mathrm{pl}$; the second one, by the spread of the $3 \mathrm{pl}$ onto the reflexive; in the third one, the $3 \mathrm{pl}$ shifted over to the accusative and, eventually, the fourth one shows the emergence of the $3 \mathrm{pl}$ also in the verb of an embedded sentence. The rest of elements were inflected in 2pl (Lara 2012). Moreover, this type of diffusion clearly matched the wave model pattern. According to Chambers and Trudgill (1980) and Wolfram and Schilling-Estes (2003), the wave model states that within a phenomenon that produces several innovations, each of these innovations will arise in a specific point, called focus or epicentre. Likewise, this focus or epicentre will make the innovations extend gradually to its periphery. Then, once the periphery has adopted each innovation, it will spread it to its outlying areas until the phenomenon fades. Therefore, the more proximate to the focus, the more innovative the stages of the phenomenon are; while the further away from the focus the more conservative the phases of the phenomenon are.

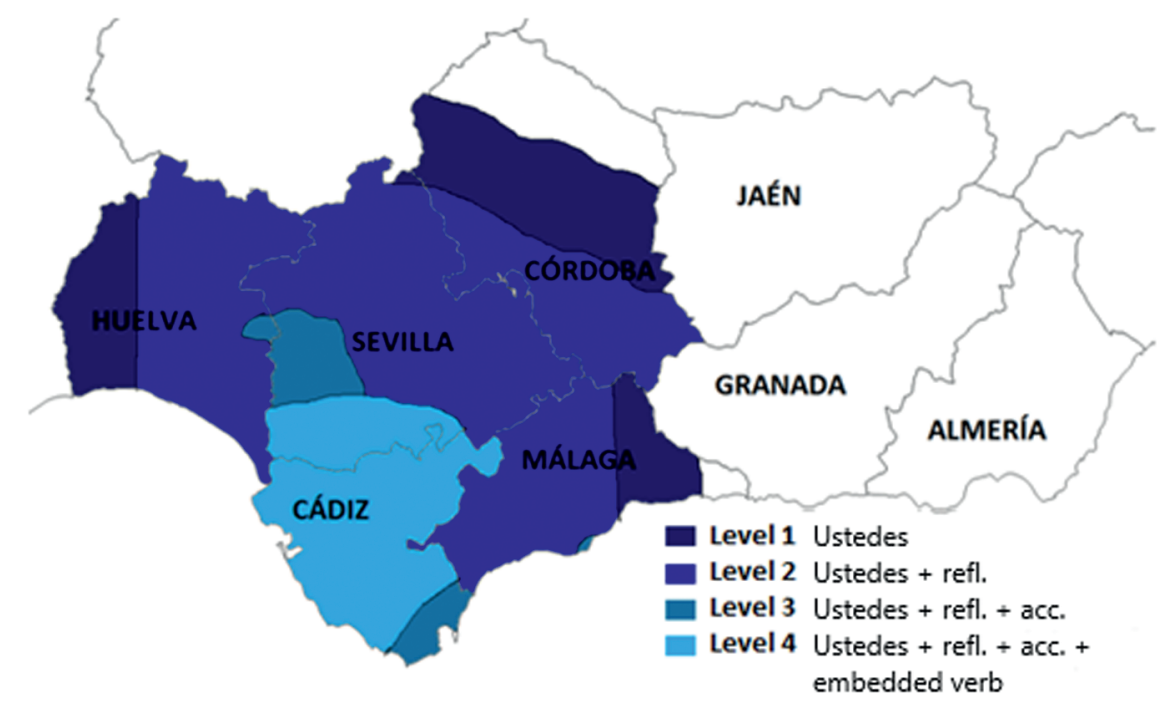

Map 2: Geographical diffusion pattern in ALPI data

If these facts are applied to Map 2, the zone where the 3pl is attested in the embedded verb also produces $3 \mathrm{pl}$ inflections in the accusative, the reflexive and, of course, in the stressed pronoun. Thus, southern Seville and the province of Cadiz are the focus of the ustedes phenomenon and the more elements are inflected in 3pl, the more innovative the evolution of this phenomenon is. 
From a grammatical point of view, the agreement extends gradually throughout the different syntactic elements anchoring ustedes $(6 \mathrm{a}-\mathrm{d})$.

(6) a. Ustedes no os disteis cuenta de cuándo os vieron You.3PL NEg REFL.2PL. notice.2Pl.PAST. when ACc.2PL. See.3PL.PAST. mientras caminabais while walk.2PL.imp. ('You did not notice that they saw you while you were walking')

b. Ustedes no se disteis cuenta de cuándo os vieron You.3Pl Neg REFl.3Pl. notice.2Pl.PAST. when ACc.2Pl. see.3PL.PAST. mientras caminabais while walk.2PL.imp. ('You did not notice that they saw you while you were walking')

c. Ustedes no se disteis cuenta de cuándo los vieron You.3Pl Neg REFl.3Pl. notice.2Pl.PASt. when ACc.3PL. see.3Pl.PAST. mientras caminabais while walk.2PL.imp.

('You did not notice that they saw you while you were walking')

d. Ustedes no se disteis cuenta de cuándo los vieron You.3PL Neg REFl.3Pl. notice.2Pl.PASt. when ACc.3Pl. see.3Pl.PAST. mientras caminaban while walk.3PL.IMP.

('You did not notice that they saw you while you were walking')

As has been explained above, once the $3 \mathrm{pl}$ is established in one element it can pass onto the other. These data can be synthesised in the following hierarchy (i):

(i) Stressed pronoun $>$ reflexive $>$ accusative $>$ embedded verb

The emergence of the $3 \mathrm{pl}$ in one element implies its usage in the elements on the left and this is why the syntactic agreement goes rightwards in the hierarchy.

Lastly, from a pragmatic point of view, the grammatical agreement did not change, depending on the degree of politeness. Thus, formal contexts did not favour $3 \mathrm{pl}$ inflections nor informal contexts inclined informants toward 2pl inflections.

\subsection{Fieldwork}

The ALPI data did not provide information about all the syntactic elements with reference to ustedes. It lacks occurrences of datives, possessives or other verb tenses. In addition, the ALPI questionnaire was conceived to prompt one answer per pre-established sentence; hence, the data collected do not represent a quanti- 
tative sample. In order to compensate the shortcomings of this methodology and compare the current data to those extracted from this linguistic atlas and, thus, track the diachronic evolution of the ustedes phenomenon, I designed a specific method based on the dubbing of sitcoms scenes. I compiled several scenes of two quite popular sitcoms with which informants could identify themselves. Besides, these sitcoms usually show one character addressing a group of people, thus, it is a great opportunity to obtain a many $2 \mathrm{pl}$ occurrences, since the informants were asked to pretend they were the character that addressed the rest of actors and to dub the scenes they watched. Each scene prompted one specific syntactic element, thanks to a brief synopsis with lead sentences that were always expressed by the inquirer in 3pl. The informants had to make the effort to turn all those lead sentences into communication that required 2pl inflections; this is why all the data collected was spontaneously produced (Lara 2016). Table 4 shows the number of speakers and examples obtained through this method.

Table 4: Number of tokens and informants of the sociolinguistic corpus

\begin{tabular}{ll}
\hline INFORMANTS & OCCURRENCES \\
\hline 242 & 4,491 \\
\hline
\end{tabular}

All the data have been processed with a statistics programme (SPSS). Each occurrence is labelled based on its extra-linguistic and linguistic factors: gender, age, educational level, locality, province, ALPI zone (cf. Map 1) and size of the population of the locality. Additionally, the linguistic factors that have been analysed are the stressed pronoun, the reflexive pronoun, the accusative pronoun, the dative pronoun, the possessive, the verb tense, the verb mood, the modality, the type of embedded sentence and the communicative situation (formal or informal). Below, I reproduce the number of tokens and informants, on the basis of a number of their social features.

Table 5: Number of informants and tokens of the fieldwork (gender)

\begin{tabular}{lcr}
\hline & INFORMANTS & OCCURRENCES \\
\hline MEN & $117(48,3 \%)$ & $2007(44,6 \%)$ \\
\hline WOMEN & $125(51,7 \%)$ & $2484(55,4 \%)$ \\
\hline TOTAL & $242(100 \%)$ & $4491(100 \%)$ \\
\hline
\end{tabular}


Table 6: Number of informants and tokens of the fieldowrk (age)

\begin{tabular}{lcr}
\hline & INFORMANTS & OCCURRENCES \\
\hline YOUNG (YOUNGER THAN 30) & $94(38,8 \%)$ & $1956(43,5 \%)$ \\
\hline WORKING POPULATION & $94(38,8 \%)$ & $1930(42,9 \%)$ \\
\hline ELDERLY (OLDER THAN 60) & $54(22,4 \%)$ & $605(13,6 \%)$ \\
\hline TOTAL & $242(100 \%)$ & $4491(100 \%)$ \\
\hline
\end{tabular}

Table 7: Number of informants and tokens of the fieldwork (education)

\begin{tabular}{lrr}
\hline & INFORMANTS & OCCURRENCES \\
\hline HIGHER EDUCATION & $58(24 \%)$ & $1086(24,1 \%)$ \\
\hline LOWER EDUCATION & $184(76 \%)$ & $3405(75,9 \%)$ \\
\hline TOTAL & $242(100 \%)$ & $4491(100 \%)$ \\
\hline
\end{tabular}

Table 8: Number of informants and tokens of the fieldwork (population)

\begin{tabular}{lrr}
\hline & INFORMANTS & OCCURRENCES \\
\hline-5.000 INHAB. & $28(11,5 \%)$ & $489(10,9 \%)$ \\
\hline $5.000-10.000$ INHAB. & $67(27,7 \%)$ & $1202(26,7 \%)$ \\
\hline $10.000-20.000$ INHAB. & $63(26 \%)$ & $1149(25,6 \%)$ \\
\hline $20.000-100.000$ INHAB. & $18(7,5 \%)$ & $252(5,6 \%)$ \\
\hline $100.000-500.000$ INHAB. & $41(17 \%)$ & $872(19,4 \%)$ \\
\hline+500.000 INHAB. & $25(10,3 \%)$ & $527(17,8 \%)$ \\
\hline TOTAL & $242(100 \%)$ & $4491(100 \%)$ \\
\hline
\end{tabular}

The results were applied two statistical tests: the Pearson's chi squared test and a logistic regression. The former gives the real significance of an independent variable (i.e.: gender, age, etc.) and the latter orders the degree of affectedness of each significant variable. In the case of the ustedes phenomenon, the chi squared test highlighted the importance of age, educational background and size of the population of the municipality in the use of the vernacular particularity (Lara 2015). Based on this, there are currently two different behaviours: the vernacular one, in which ustedes and the spread of the 3pl furthers; and the standard one, based on the spread of the pronoun vosotros plus 2pl for informality and ustedes plus $3 \mathrm{pl}$ for formality. This last behaviour is led by middle-aged people who live in urban environments and who can be classified as cultivated (on the contrary, 
the elderly, the not very educated informants and the informants who live in rural environments usually maintain the vernacular more strongly). Maps 3 and 4 demonstrate perfectly this double tendency.

On the one hand, Map 3 shows that the use of the vernacular particularity is high or hegemonic (+66\%) in very rural environments, such as in Montoro, Pedrera or Conil de la Frontera, which do not exceed 10,000 inhabitants. At the other extreme, large cities such as Seville and Malaga show a low or null percentage of the use of the vernacular phenomenon (-33\%); in between we find intermediate towns (with approximately 50,000-150,000 inhabitants) which begin to adopt the standard pattern but they still maintain, in a relatively wide proportion, the vernacular one $(33 \%-66 \%)$.

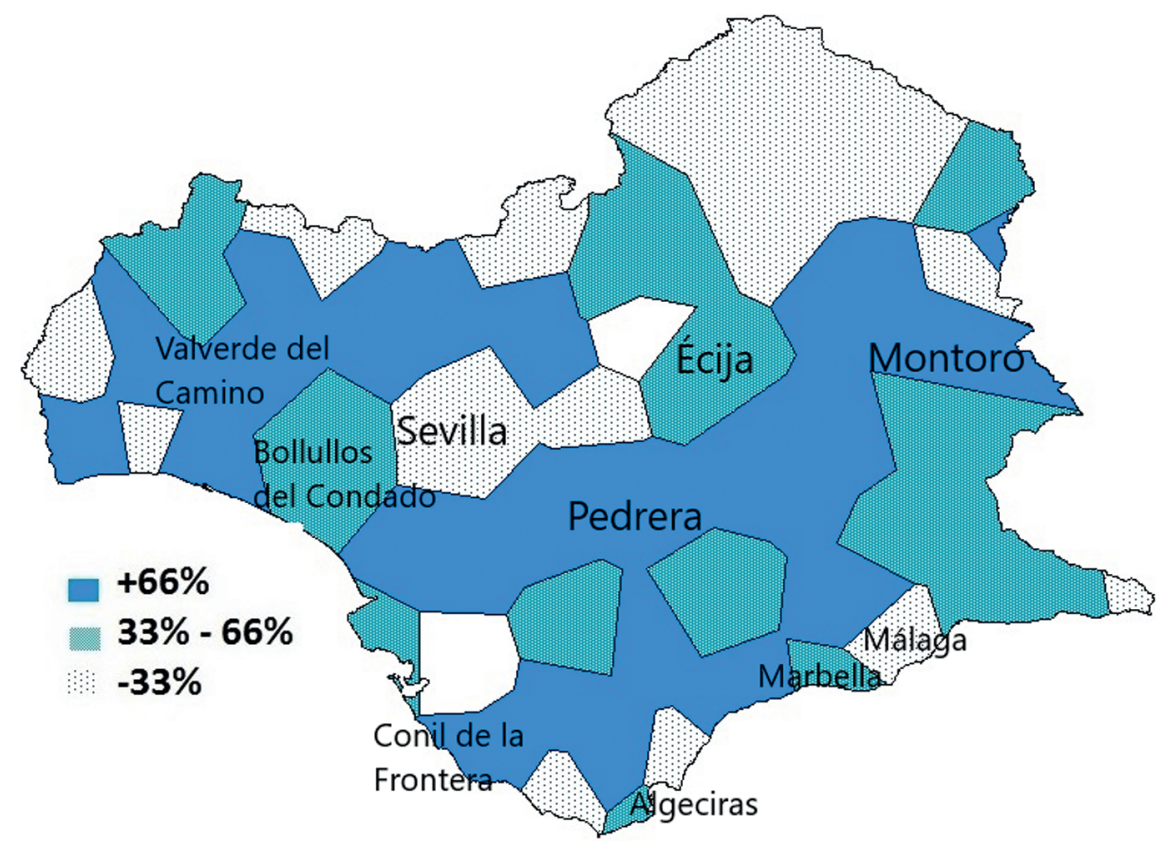

Map 3: Vernacular use based on the size of the population 


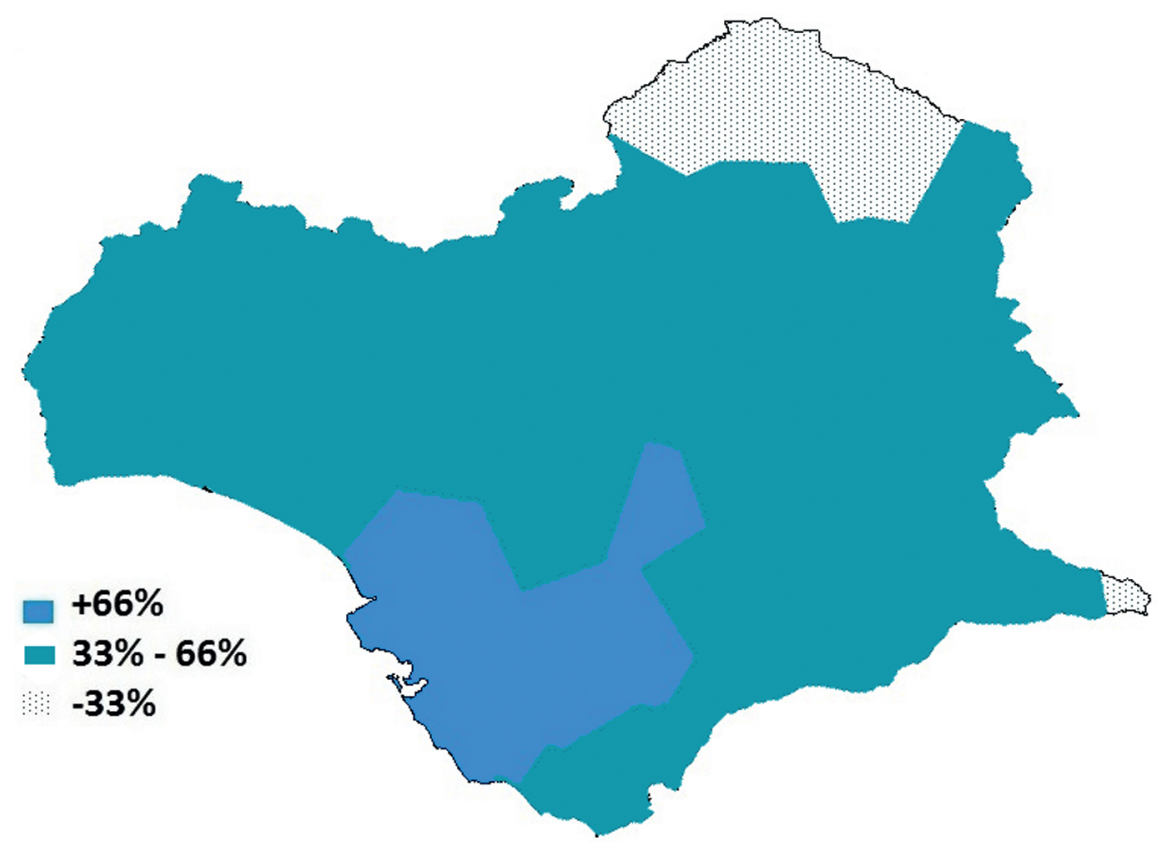

Map 4: Use of the vernacular and percentage of agreement

On the other hand, Map 4 shows that, irrespective of the social factors of the informants and the size of the population, three major areas can be identified based on the degree of maintenance of the vernacular phenomenon. On the one hand, again the areas characterised by $-33 \%$ show a low or null percentage of the ustedes phenomenon; on the other hand, the areas with $+66 \%$ present a high or overwhelming use of ustedes in detriment of the standard system. The spatial area with $33 \%-66 \%$ have an intermediate employment of the vernacular particularity. Additionally, the disagreements attested between ustedes and the verb are fewer and fewer the closer we move to the focal area ( $+66 \%)$.

As for the logistic regression, within all the variables considered important by the chi squared test, it is education that the statistics has given priority over the rest of variables, followed by age and size of the population. 


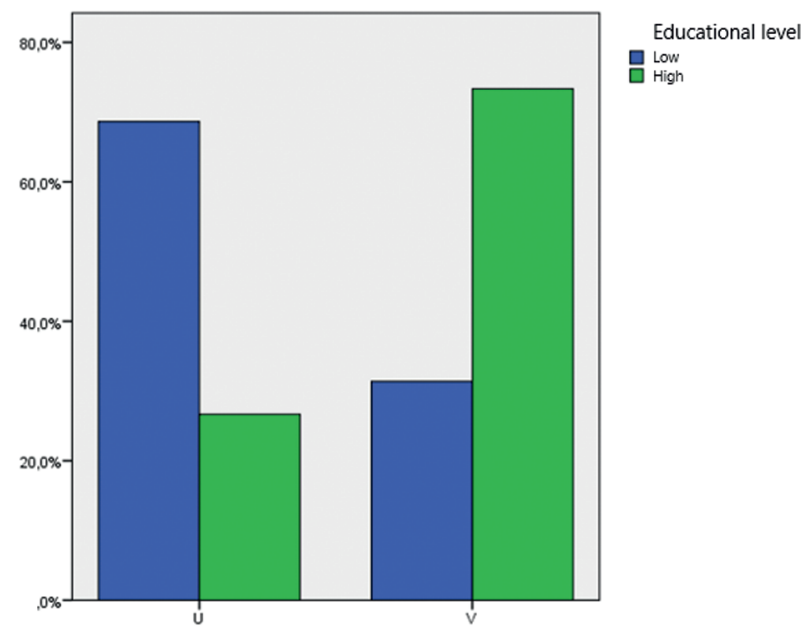

Figure 1: (Educational level)

Figure 1 demonstrates that nearly $80 \%$ of the informants with a low educational background choose ustedes for any pragmatic situation (U) whereas $80 \%$ of higher-educated speakers follow the standard model (V).

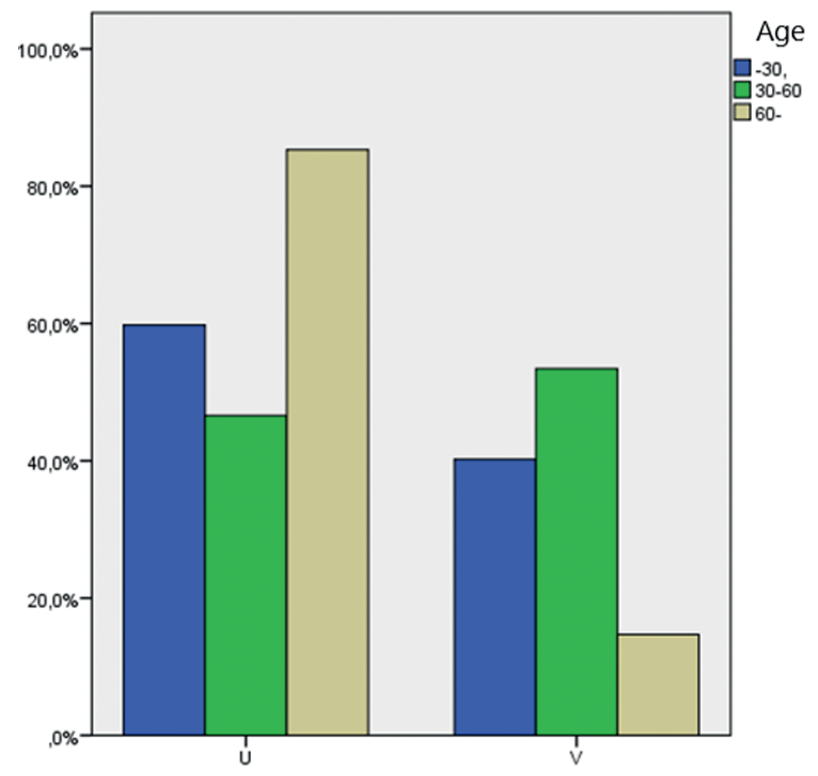

Figure 2: (Age) 
Figure 2 shows that virtually all the elderly informants that were surveyed prefer the vernacular phenomenon (U), while $60 \%$ of middle-aged people, regardless their educational level, have adopted the normative model (V). Young informants behave in exactly the opposite way to the middle-aged, since $60 \%$ of them maintain the vernacular feature.

As a conclusion, nowadays Andalusian speakers are characterised by a strong alternation between standard and vernacular, with the former emerging in urban areas and middle-aged cultivated informants, and the latter being maintained by not very educated speakers from rural environments. But, as this paper does not aim to analyse the social conditioning features that affect the ustedes phenomenon, I will begin below to introduce the linguistic results and the theoretical discussion that can validate the data.

\section{Discussion}

Although this article attempts to explain why ustedes has been a topic and, in some places, it has turned into a subject, it is relevant to point out that when ustedes behaves completely as a subject, the $3 \mathrm{pl}$ starts spreading throughout the rest of elements that refer to this pronoun, following the next continuum (ii).

(ii) Stressed pronoun $>$ reflexive $>$ verb $>$ accusative $>$ dative $>$ possessive

The prompt of the $3 \mathrm{pl}$ agreement in one element presupposes its emergence in the elements on the left. Hence, if the informants produce the $3 \mathrm{pl}$ in datives, they will also produce it in accusatives, verbs, reflexives and stressed pronouns. The innovation always goes rightwards in the hierarchy (for more information, Lara, 2018). As has been stated, I will pass now to analyse why ustedes induces person mismatches between reflexive and verb and at what stage all these elements fully agree. Map 4 shows that there are three diverse areas within the phenomenon, depending on its incidence. Interestingly, each of them exhibits a different linguistic behaviour, being the $-33 \%$ area the one with more disagreements; the $33 \%-66 \%$ area however is characterised by having an intermediate proportion of disagreements, while the $+66 \%$ area shows a virtual consistency in agreeing ustedes, the reflexive and the verb in $3 \mathrm{pl}$. I will focus now on each of them. 


\subsection{Area $-33 \%$}

As has been mentioned, the area with $-33 \%$ shows the wider proportion of disagreement between ustedes and the verb (7-10).

(7) Ustedes, no tenéis nómina

You-3PL NEG have.2PL.PRs. income

('You do not have incomes')

(8) Ustedes, habéis desorganizado mi casa

You-3PL have.2PL.PRs. mess up.PCP my house

('You have messed up my house')

(9) Ustedes, no sois solventes

You.3Pl NEG be.2Pl.PRs. solvent

('You are no solvent')

(10) Ustedes, estáis en paro

You-3PL be-2PL.Prs. in unemployment

('You are unemployed')

In (7-10), the expression of ustedes has not induced the normative 3pl agreement. Instead, the informants have produced a verb inflected in $2 \mathrm{pl}$. However, as can be noticed, they have made a pause between the pronoun and the rest of the sentence; this is why it is written with a coma in between. The instances found in this area regarding the pronoun ustedes behave as topics and not properly as subjects. Topics need to be recovered anaphorically within the sentence but, as Spanish is a pro drop language, the subject that refers to ustedes can be elided. Therefore, (7-10) are really produced as (11-14).

(11) Ustedes, (vosotros) no tenéis nómina You-3PL you.2PL NEG have.2PL.PRs. income ('You do not have incomes')

(12) Ustedes, (vosotros) habéis desorganizado mi casa You-3PL you.2PL have.2PL.PRs. mess up.PCP my house ('You have messed my house up')

(13) Ustedes, (vosotros) no sois solventes

You.3PL you.2PL NEG be.2PL.PRs. solvent

('You are no solvent')

(14) Ustedes, (vosotros) estáis en paro You-3PL you-2PL be-2PL.PRs. in unemployment

('You are unemployed') 
(11-14) demonstrate that ustedes does not work as the real subject, but it is the topic of the sentence, anchored by the pronoun vosotros not produced phonetically because of the pro drop parameter of the Spanish language. This can be compared to the statement made by the RAE (2009), which affirms that western Andalusia produces the concatenation of two personal pronouns in the second person plural system, as (15) shows.

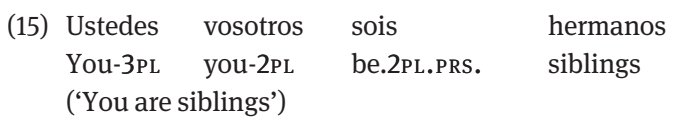

The difference between the instances collected by the RAE and mine is the elision of one of the two pronouns.

To summarise, the zone characterised by the $-33 \%$ of use of the vernacular phenomenon also presents a low percentage of agreement between ustedes and the verb, which leads to think that ustedes is not really a subject, but a topic, as RAE (2009) has already pointed out.

\subsection{Area $33 \%-66 \%$}

The area with $33 \%-66 \%$ provides an intermediate use of the vernacular phenomenon and also a higher amount of agreement matches between ustedes and the verb although the person mismatches are still widely attested. (16-23) show the linguistic behaviour in this area.

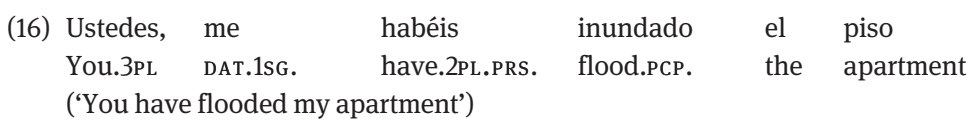

(17) Ustedes, no tenéis nómina

You-3PL NEg have.2PL.PRs. income

('You do not have incomes')

(18) Fuisteis, ustedes

Be.2PL.Pst. you.3PL

('You did it')

(19) No negarse

NEg refuse.INF+REFL.3PL.

('Don't deny it') 
$\begin{array}{lll}\text { (20) ¿Cómo } & \text { se } & \text { llamáis? } \\ \text { How } & \text { REFL.3PL. } & \text { call.2P.PRS. } \\ \text { ('What are your namaes?') } & \end{array}$

(21) Creo que se deberíais preocupar de vuestros asuntos Think.1sG.PRs, that REFL.3PL should.2PL. worry.INF. about your.2PL affairs ('I think you should mind your own business')

(22) Ustedes se imagináis cómo estoy You.3PL REFL.3PL imagine.2PL.PRs, how be.1SG.PRS. ('You can’t imagine how I feel')
(23) No se vayáis ustedes a creer Neg REFl.3Pl. go.2PL.PRs.subJv. you.3Pl. to believe.3PL ('Don't believe it')

As (16-23) show, the intermediate zone still construes a verb in 2pl, but it induces $3 \mathrm{pl}$ in the reflexive. In some areas, ustedes is a topic, but (22-23) demonstrate that ustedes does not need the pause any more in certain areas close to the focus. It is here when both $3 \mathrm{pl}$ and $2 \mathrm{pl}$ agreements can emerge and coexist even in the same syntactic functions. (24-26) show that, as the RAE put forward for the subject, we can find two different pronouns concatenated and with the same syntactic reference.
(24) Se os queréis ir
REFL.3PL REFL.2PL want.2PL.PRS. go.INF
('You want to go')
(25) Se os he visto
REFL.3PL REFL.2PL have.1SG.PRS. See.PCP
('I have seen you')
(26) Hacer lo que se os dé la gana
Do.INF. what REFL.3PL REFL.2PL feel like
('Do what you feel like')

The informants produced two reflexive, accusative or dative pronouns with reference to the same entity, one of them agreed in $3 \mathrm{pl}$ and the other one in $2 \mathrm{pl}$, always in this order. But even verbal desinences can show this coexistence (2728).

(27) $\mathrm{Me}$ abrierois los grifos

DAt.1sG. open.3PL+2PL.PST. the taps

('You opened the taps') 
(28) Intentarois entrar

Try.3PL +2PL come in.INF

('You tried to come in')

(27-28) show that the verb desinence has a first ending in 3pl (-ro) and a second ending in 2pl (-is). Again, the speakers chose to express two different agreements at the same time with reference to the same entity.

\subsection{Area $+66 \%$}

Lastly, the zone characterised by $+66 \%$ provides a stronger use of the vernacular phenomenon as well as a higher percentage of ustedes and verb agreed in 3pl. See (29-33).

(29) Inundaron el piso

Flood.3PL.PST. the apartment

('You flooded my apartment')

(30) Déjenme

Leave.3PL.PRs.SBJV +1sG.ACc

('Leave me alone')

(31) Son ustedes las que entraron en mi piso

Be.3PL.PRs. you.3PL who enter.3PL.PST. in my apartment

('It was you who entered my apartment')

(32) Ustedes me han pedido un crédito

You.3PL 1SG.DAt. have.3PL.PRs. request.PCP. a loan

('You have requested a loan')

(33) Ustedes iban saliendo por la puerta

You.3PL go.3PL.IMPF. go out.GER. through the door

('You were heading for the door')

Regardless of whether the pronoun ustedes is expressed or omitted, most of the focal area already agrees the verb in $3 \mathrm{pl}$ with ustedes. Of course, in this area, the reflexive also receives $3 \mathrm{pl}$ agreement and we do not find person mismatches or a concatenation of two person inflections as we found in the intermediate area.

To sum up, the fall of vosotros and the emergence of ustedes as the only $2 \mathrm{pl}$ pronoun in western Andalusia undergoes a series of stages that can be synthesised in Table 9. 
Table 9: Evolution of the agreement

\begin{tabular}{|c|c|c|c|}
\hline & STAGE 1 & STAGE 2 & STAGE 3 \\
\hline \multicolumn{4}{|c|}{ Unagreement ustedes } \\
\hline \multicolumn{4}{|c|}{$\begin{array}{l}\text { Partial agreement ustedes and } \\
\text { verb / reflexive }\end{array}$} \\
\hline $\begin{array}{l}\text { Agreement usted } \\
\text { reflexive }\end{array}$ & & & \\
\hline
\end{tabular}

Stage 1 is mainly witnessed in the area characterised by $-33 \%$ of vernacular use; stage 2 is mainly attested in the intermediate area with a $33 \%-66 \%$ of vernacular use; and stage 3 is common in the area with a $+66 \%$ of use of the vernacular particularity.

These stages coincide with the path that topics undergo until they become subjects. Givón $(1975,1990)$ remarks that subjects are topics that have been reanalysed as such. For him, the path from topic to subject must start from a marked construction and end in an unmarked construction, as (iii) shows.

(iii) The man, he came $\rightarrow$ The man he came $\rightarrow$ The man came

In the first step, we see a marked construction, where the topic has been located in the left periphery, out of the sentence and it is retaken within the sentence by an anaphor. As this author and Li (1975) or Hopper and Trauggott (2003) state, topics are formed outside the sentence but have to be recovered inside it. However, this anaphor does not have to receive the same syntactic traces as the element it is related to. The topic advances the aboutness and it emerges to make explicit the theme with which the speech deals. Back to (iii), the continuous emergence of the marked construction makes the reinterpretation of the topic into the subject, since the topic is located in the typical place where subjects are formed. But before its complete reinterpretation into subject, the topic coexists with its anaphor under a construction in which the topic is becoming a subject but it still needs an anaphor, which behaves as a subject clitic. This path can be attested in Creole French, as (34-35) show.

(34) Lé dié i sont malin The god he be.3PL.PRs. clever ('God is clever')

(35) Lé démon i pensé

The demon he think.PCP.MASC.SG.

('The devil has thought') 
Finally, the complete reanalysis of the ancient topic as the subject makes the subject clitic or old anaphor disappear. In this construction, unmarked, the topic has completely been reinterpreted as the subject.

This is exactly what happens in the ustedes phenomenon and we can even observe the diachronic path thanks to the instances collected during my fieldwork. The first stage (The man, he came) is reproduced below.

(36) Ustedes, no tenéis nómina You-3PL NEg have.2PL.PRs. income ('You do not have incomes')

(37) Ustedes, habéis desorganizado mi casa You-3PL have.2PL.PRS. mess up.PCP my house ('You have messed my house up')

(38) Ustedes, no sois solventes You.3PL NEG be.2PL.PRs. solvent ('You are no solvent')

(39) Ustedes, estáis en paro You-3PL be-2PL.PRS. in unemployment ('You are unemployed')

Ustedes is expressed before a pause and its reference is recovered sometimes with a silent pronoun because of the pro drop parameter and sometimes it is explicitly expressed, as RAE (2009) has recorded.

The second stage (The man he came) is reproduced below.

(40) Se os queréis ir

REFL.3PL REFL.2PL want.2PL.PRs. go.INF

('You want to go')

(41) Se os he visto

REFL.3PL REFL.2PL have.1SG.PRS. See.PCP

('I have seen you')

(42) Hacer lo que se os déla gana

Do.INF. what REFL.3PL REFL.2PL feel like

('Do what you feel like')

(43) $\mathrm{Me}$ abrierois los grifos

DAt.1SG. open.3PL+2PL.PST. the tabs

('You opened the tabs') 


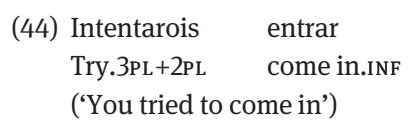

In this case, the pause has disappeared but the conversion of the topic into the subject is still in progress. This makes it necessary to express the old subject, since the new subject still possesses a topical behaviour. In (40-42), as Spanish is a pro drop language, the two elements are anchored by a reflexive agreed in $3 \mathrm{pl}(\mathrm{se}$ ) and another one in $2 \mathrm{pl}(\mathrm{os})$. The first one refers to ustedes and the other one refers to vosotros. It is even possible to make reference to both elements inside the verb: the ending -ro anchors ustedes and -is does so with vosotros (43-44).

Spanish is characterised by having the possibility of laying the topic and subject in a relatively free position. Although the topic can be inserted anywhere, the left periphery is the most common place. It is precisely this position that triggers the conversion of the topic into the subject, as Givón (1975), Lehmann (1975) or Li (1975) hold. The most usual syntactic structures to be topicalised in Spanish are objects and experiencers. Compare (45-49).

(45) A mí, me gusta el chocolate To me, 1sG.DAT like.3sg.prs. the chocolate ('I like chocolate')

(46) A él, lo vi ayer de compras To him 3sg.Acc. see.1sG.PST. yesterday shopping ('Yesterday I saw him shopping')

(47) Lo que a mí más me molesta es el ruido What to me more 1sG.Dat. annoy.3sg.Prs. be.3sg.prs. the noise ('What really annoys me is the noise')

(48) A mí, me da igual To me 1sG.Dat. give.3sg.PRs. same ('I do not mind')

(49) Los ordenadores, yo de esas maquinas no sé nada The computers I about those machines NEG know.1sG.PRs. nothing ('Regarding computers, I don't know anything about those machines')

In (45-49), Spanish tends to make the experiencer more prominent and thus it places it in the left periphery. This requires the recovery of the entity through an anaphora within the sentence which may or may not agree. However, the frequency of sentences such as (45) or (48) have triggered the conversion of the 
topicalised element in a sort of subject through a valency change. Currently, colloquial Spanish can have (50-51).

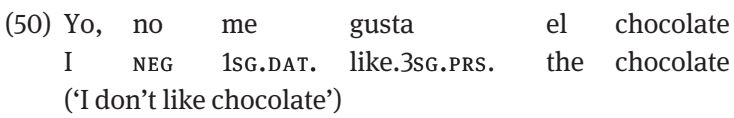

(51) Yo, me da igual lo que digan

I 1sG.DAT give.3SG.PRS. same what say.3PL.PRS.SBJV ('I don't care what they say')

(50-51) demonstrate that the former dative construction has been turned into a subject pronoun although it is still maintained in the left periphery and it is recovered through the clitic me. As in the case of ustedes, it is the element positioned in the left periphery which starts displacing the existent one, but it is infrequent for a topic laid in a right or intermediate position to become the subject. The examples (50-51) shown above seem to be undergoing the first modifications that verbs such as like underwent in Early Modern English. According to Allen (1995), Medieval English used to have a theme inflected in nominative and an experiencer inflected in dative although the non-marked order was experiencer + verb + theme. The greater the frequency of this order in this type of constructions provoked a valency change in its elements, since the experiencer started receiving nominative case and the theme, dative case. Gradually, the experiencer became the normal subject and the theme, the normal object, as we know it today.

Nevertheless, Spanish and English are not the only languages that have turned certain topicalised constructions into subject-like constructions. Kayne (2003, 2005) has documented the loss of the clitic subject in third person and its displacement by the topic pronoun (52-53).
(52) Lui (,)
(il)
a
téléphoné
3sg.masc.
(3sG.masc.clit.) have-3sG.PREs.Ind. phone-PCP. ('He has phoned')
(53) $\operatorname{Eux}($,
(ils)
ont
téléphoné
3PL.MASC.
(3Pl.masc.clit.) have-3Pl.PREs.Ind. phone-PCP.
('They have phoned')

However, the right-topicalised construction does not promote the loss of the subject clitic (54). 
(54) *(il) a téléphoné (,) lui

(3SG.MASC.CLIT.) have-3SG.PRES.IND. phone-PCP. 3SG.Masc.

('He has phoned')

Hopper and Traugott (2003) also point out that the left periphery favours the conversion of topics into subjects, owing to the natural tendency of subjects to be placed before the verb or at the beginning of the sentence. If we take a look at the examples collected by my fieldwork, we realise that the concatenation of the two pronouns or the two anaphors follows the same order: $3 \mathrm{pl}+2 \mathrm{pl}$, since it is ustedes the topicalised element and not vosotros. As in the examples provided with by Givón or Kayne, regarding French and English, the new agreement or element is first expressed by displacing gradually the existent one, which occupies the second position but not the other way around.

Another example of the path from topic to subject can be found in Old French. According to Adams (1987), old French had a V2 structure and was pro drop. However, the speakers started expressing more and more frequently the topic, which in the majority of cases were also the real subjects. The regularity in the production of this structure as well as its taking place in the left periphery gave rise to the obligation of expressing the subject and of doing so before the verb. This changed the word order structure to the one we know today.

The current standard Italian third person pronouns also underwent a topicalisation process already attested in the Early Middle Ages. Rohlfs (1968) and Ernst et al. (2008) point out that lui, lei and loro started coexisting with the forms egli, ella, essi, esse which were the normative third person subject pronouns.

(55) Lui, egli sa ogni cosa

Him he know.3sg.PRs. every thing

('He knows it all')

With time, this construction became common and the former subject pronoun cliticised.

(56) Lui e' sa ogni cosa

Him he know.3sg.prs. every thing ('He knows it all')

Finally, the clitic disappeared and the oblique pronoun became subject as we know it today.

(57) Lui sa ogni cosa

He know.3sg.prs. every thing

('He knows it all') 
Again, the new form is placed in the left periphery, followed by a coma and the normative element that it tries to replace. With time, the topic starts behaving as a subject, since the coma disappears but it still needs to be anchored by an element, so both coexist in the sentence. Eventually, the former element ends up disappearing and the new one occupies its place, always following the same word order (from left to right) and the same evolution: topic $\rightarrow$ topic / subject $\rightarrow$ subject.

There are several studies about the process of topicalisation in the Spanish language, but they mainly deal with plural noun phrases and the agreements that these noun phrases induce. Compare (58-60).
(58) Los estudiantes somos jovenes
The students be.1PL.PRs. young
('We students are young')
(59) Los estudiantes sois jovenes The students be.2PL.PRs. young
('You students are young')
(60) La gente somos muy egoistas The people be.1PL.PRs. very selfish ('The people, we are selfish')

Fábregas (2008) and RAE (2009) claim that the sentences exemplified in (58-60) are completely grammatical and common in Spanish and they do not present unagreement, due to the fact that they really contain a silent element that induces the agreement with the verb. Therefore, (58-60) are really (61-63).
(61) Los estudiantes (nosotros) somos jovenes
The students we be.1PL.Prs. young
('We students are young')
(62) Los estudiantes (vosotros) sois jovenes
The students you be.2PL.Prs. young
('You students are young')
(63) La gente (nosotros) somos muy egoistas The people we be.1PL.PRs. very selfish
('The people, we are selfish')

Hence, the apparent mismatches are owed to silent elements that are syntactically in the sentence but which simply are not expressed phonetically. And, contrary to Fábrega's explanation, Spanish can have this sort of silent constructions with singular elements too. According to Abadía de Quant (1992) or Fontanella de Weinberg (1979), the imposition of the pronoun vos as 2sg in Argentina Spanish 
during the $19^{\text {th }}$ century began in topicalised sentences, in which vos was recovered by a silent element and a verb that did not agree with te topic, since it was inflected in tú morphology. With time, vos turned into a subject and the verb started developing an own agreement that matched with vos, as we know it nowadays. In fact, unstressed pronouns that refer to vos still possess tú morphology. Likewise, other varieties of the Spanish spoken in Latin America exhibit disagreements with vos, as the verb is always construed in tú morphology. In these places, vos is mainly used as a vocative or a as a topic and has not ousted tú yet from the paradigm (Hummel et al.2010). The pronoun tú, therefore, is silent or is not simply expressed phonetically because of the pro drop parameter I have referred to throughout.

Kayne (2007) has found this same pattern in Italian. According to him, a sentence like (64) can only be explained because there is a silent element that is not phonetically produced (65).

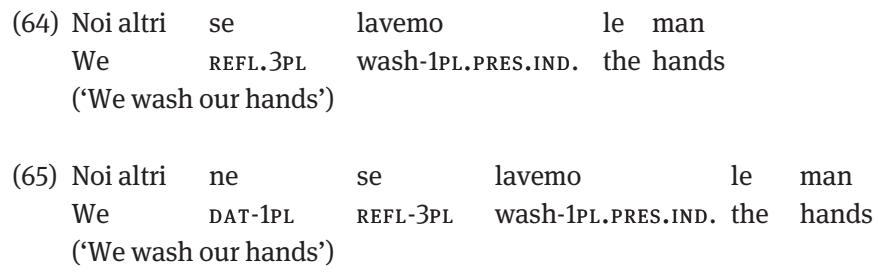

Even for French he puts forward the same argument, as (66-67) show, where me refers to person and se to the notion of reflexivity.
(66) Je me lave les mains
I DAT.1SG. wash-1sG.PRES.IND. the hands ('I wash my hands')
(67) Je me se lave les mains
I DAT.1SG REFL.3P wash-1SG.PRES.IND. the hands ('I wash my hands')

So, if we take into account the behaviour of Spanish regarding topics and the cross-linguistic evidence, (2) should really be (68) in the ustedes phenomenon.
(68) Ustedes [vosotros] se [os]
('You [you] stay at home')
You-3PL [you-2PL] REFL-3PL [REFL-2PL]

While ustedes is anchored by a $3 \mathrm{pl} s e$, the verb agrees with the real subject (vosotros), which is not made explicit, the same as its reflexive element (os), which has not been produced phonetically either. 


\section{Conclusions}

The use of ustedes as the single $2 \mathrm{pl}$ pronoun, at the expense of the standard diaphasic distinction between vosotros and ustedes, induce both $3 \mathrm{pl}$ and $2 \mathrm{pl}$ agreements. Although ustedes must agree in $3 \mathrm{pl}$, the literature has always remarked the unagreement between the pronoun and the verb or reflexive, which were always inflected in 2pl. However, my recent research demonstrates that ustedes behaves as a topic and the so-called unagreements are really in appearance. The data provided with by the corpus show three different geographical stages that coincide with three different grammatical stages in the linguistic behaviour of ustedes and its agreements. Specifically, the first one presents a low percentage of agreement between ustedes and the verb as well as a low percentage of the vernacular use. In this phase, ustedes is a topic, recovered by a covert element (vosotros) that is not phonetically expressed and which is the real subject. The second stage shows an intermediate use of the vernacular as well as an increase of the agreements between ustedes and the verb, the frequency of which is still far from being systematic. In this phase, ustedes keeps on behaving as a topic but it has already acquired certain subject features. Lastly, the following phase is characterised by having a high percentage of the vernacular particularity and a systematic agreement in 3pl between ustedes and the verb. This area has completely turned ustedes from a topic into a subject.

In the process of conversion toward a subject, the topic (ustedes) is recovered anaphorically by an element that sometimes is silent and sometimes is overtly expressed. This is due to the pro drop character of Spanish, which can elide the subject (vosotros in the two first grammatical phases) and, therefore, possess an apparent agreement mismatch. Such a linguistic behaviour is commonplace in Spanish but is has likewise been attested cross-linguistically. In the Andalusian phenomenon, the order in which the new and the old elements emerge always obey the same pattern: ustedes - vosotros. It is so in the first period of the phenomenon, in which ustedes is positioned in the left periphery, followed by the real subject (vosotros); it is even so in the intermediate phase, in which the two elements are overtly expressed more often ( $s e+o s ;-r o+-i s)$. Thus, the Andalusian vernacular phenomenon is characterised by the same linguistic behaviour witnessed in other phenomena from colloquial French, Middle English or Italian, and it strictly follows the process described by Givón $(1975,1990)$ regarding the universal tendency of topics to be reanalysed as subjects. 


\section{Works cited}

Abadía de Quant, Inés (1992): “La relación pronominal-verbal de segunda persona singular en el español de Corrientes durante el siglo XIX, su comparación con la situación en Buenos Aires”, Revista argentina de lingüística 8, pp. 31-46.

Adams, Marianne (1987): "From old French to the theory of pro-drop", Natural language and linguistic theory 5, 1, pp. 1-32.

Allen, Cynthia (1995): Case marking and reanalysis. Grammatical relations from Old to Early Modern English, Oxford: Clarendon Press.

Alvar, Manuel (1996): Manual de dialectología hispánica, Barcelona: Ariel.

Cano, Rafael (2004): Historia de la lengua española, Barcelona: Ariel.

Chambers, Jack / Trudgill, Peter (1980): Dialectology, Cambridge: Cambridge University Press.

Ernst, Gerhard et al. (2008): Romanische Sprachgeschichte, Berlin / New York: Mouton de Gruyter.

Fábregas, Antonio (2008): "Variación en forma morfológica de los pronombres de primera y segunda persona del plural”, Revista española de lingüística 38, pp. 155-184.

Fernández Martín, Elisabeth (2012): La oposición vosotros/ustedes en la historia del español peninsular (1700-1931), Granada: Universidad de Granada.

Fontanella de Weinberg, Beatriz (1979): “La oposición cantes/cantés en el español de Buenos Aires”, Thesaurus XXXIV, pp. 72-83.

Givón, Talmy (1975): “Topic, pronoun and grammatical agreement”, in: Li, Charles (ed.): Subject and topic, New York: Academic Press Inc, p p. 149-188.

Givón, Talmy (1990): Syntax, a functional-typological introduction, Amsterdam / Philadelphia: John Benjamins.

Hopper, Paul / Traugott, Elizabeth (2003): Grammaticalization, Cambridge: Cambridge University Press.

Hummel, Martin et al. (2010): Formas y fórmulas de tratamiento en el mundo hispánico, Mexico DF: COLMEX / Karl-Franzens Universität Graz.

Kayne, Richard (2003): “Person morphemes and reflexives in Italian, French and related languages", in: Tortora, Christina (ed.): The syntax of Italian dialects, Oxford: Oxford University Press, pp. 102-136.

Kayne, Richard (2005): Movement and silence, Oxford: Oxford University Press.

Kayne, Richard (2007): Some silent first person plurals, New York: New York University.

Lapesa, Rafael (2000): Estudios de morfosintaxis histórica del español, Madrid: Gredos.

Lara, Víctor (2012): “Ustedes instead of vosotros and vocês instead of vós: an analysis through the Linguistic Atlas of the Iberian Peninsula (ALPI)”, Dialectologia Special Issue 3, pp. 57-93.

Lara, Víctor (2015): “Allocutive pronouns in Andalusia and their tendency toward standardization”, Dialectologia Special Issue 5, pp. 241-260.

Lara, Víctor (2016): "Spontaneous dubbing as a tool for eliciting linguistic data: the case of second person plural inflections in Andalusian Spanish”, in: Côté, Marie-Hélène et al. (eds.): The future of dialect: selected papers from Methods XV, Berlin: Language Science Press, pp. 261-281.

Lara, Víctor (2018): “Relaciones de caso y extensión de la concordancia en el español peninsular y el portugués europeo", Revista de filología española 98, 1, pp. 85-110..

Lehmann, Winfred (1975): “From topic to subject in Indo-European”, in: Li, Charles (ed.): Subject and topic, New York: Academic Press Inc, p p. 445-456. 
Li, Charles (1975): Subject and topic, New York: Academic Press Inc.

Menéndez Pidal, Ramón (2005): Historia de la lengua española, Madrid: RAE / Fundación Menéndez Pidal.

Mondéjar, José (1970): El verbo andaluz: formas y estructuras, Madrid: CSIC.

Penny, Ralph (2004): Variación y cambio en español, Madrid: Gredos.

Real Academia Española and Asociación de Academias de la Lengua Española (2009): Nueva gramática de la lengua española, Madrid: Espasa.

Rohlfs, Gerhard (1968): Grammatica storica della lingua italiana e dei suoi dialetti, Torino: Einaudi.

Sanchís Guarner, Manuel et al. (1962): “El Atlas lingüístico de la Península Ibérica (ALPI). Trabajos, problemas y métodos”, in: Actas del IX Congreso Internacional de Lingüística Románica, Lisbon: Centro de Estudios Filológicos, pp. 113-120.

Wolfram, Walt / Schilling-Estes, Natalie (2003): “Dialectology and Linguistic Diffusion”, in: Joseph, Brian; Janda, Robert (eds.): The Handbook of Historical Linguistics, Malden: Blackwell, pp. 713-735. 